UDC 544.476

V.V.Sobolev ${ }^{1}$, Dr. Sc. (Tech.), Prof., orcid.org/0000-0003-1351-6674,

N. V. Bilan ${ }^{1}$, Cand. Sc. (Geol.), Assoc. Prof., orcid.org/0000-0002-4086-7827,

O. S. Baskevych ${ }^{2}$, Cand. Sc. (Phys.-Math.), Senior

Research Fellow,

orcid.org/0000-0002-3227-5637,

L. I. Stefanovich ${ }^{3}$, Dr. Sc. (Phys.-Math.), Senior

Research Fellow,

orcid.org/0000-0003-2534-8479
DOI: $10.29202 / \mathrm{nvngu} / 2018-4 / 7$

1 - National Mining University, Dnipro, Ukraine, e-mail: velo1947@ukr.net

2 - State Higher Educational Institution "Ukrainian State University of Chemical Engineering”, Dnipro, Ukraine, e-mail: abaskevich@ukr.net

3 - Institute of Physics for Mining Processes of the National Academy of Science of Ukraine, Dnipro, Ukraine, e-mail: listef2591@ukr.net

\title{
ELECTRICAL CHARGES AS CATALYSTS OF CHEMICAL REACTIONS ON A SOLID SURFACE
}

Purpose. To determine the change dependency of the potential energy of the chemical bond of a diatomic molecule on the value of the point charge and its distance to the bond using quantum mechanical calculation.

Methodology. Numerical simulation of a quantum mechanical system consisting of a point charge and a diatomic molecule interacting with each other.

Findings. The quantum-mechanical problem of the effect of an external Coulomb center on the chemical bond of diatomic molecules is solved.

Originality. A quantum mechanical model of a physical system consisting of three interacting Coulomb centers (there is a chemical bond between two of them) is developed. The model makes it possible to understand the dynamics of the interaction of a molecule with an ion, the charge of which can be characterized by either integers or fractional numbers. The change in the energy of the chemical bond in the ion field depending on the distance to the bond and the magnitude of the charge is established.

Practical value. The developed technique for calculating the energy of a chemical bond as a function of the magnitude of the electric charge was used in the development of the method for growing single crystals of metastable diamond, in calculating the limits of the chemical bond stability in metal azides, in developing the way of additional harmful gases formation during rock blasting and in calculating the stability of nanoscale hydrocarbon chains in coal, and others. The method can be used to decide on the catalyst and control the catalytic reactions.

Keywords: catalysis, electron, charge, modeling, quantum mechanics, chemical bond

Introduction. The physical and chemical state of the surface of a solid body differs fundamentally from its internal structure by the presence of incomplete bonds, local energy levels, adsorbed atoms, ions, and molecules, distorted and strained bonds [1]. The surface properties are determined by quantum effects, the presence of disorder, the nature of the defects and their distribution density, structural and energy inhomogeneity, fluctuations of shape, energy, and charge density, diffusion processes, and so forth. The surface atomic layer has excess surface energy as compared to the particle energy inside the crystal because it is saturated with defects of various origins.

Presence of dangling or incomplete bonds makes the arrangement of surface atoms in regular lattice sites energetically unfavorable. Atoms shift from their places, the lattice on the surface is reconstructed. In this case, the interatomic distances and the energy of the interatomic bonds differ in magnitude from the analogous parameters characterizing the interatomic lattice bonds throughout the crystal. It is also known that the atomic structure of different crystallographic faces is different.

Knowledge of the causes of the origin and regularities of the behavior of surface physical and chemical

(C) Sobolev V.V., Bilan N. V., Baskevych O. S., Stefanovich L. I., 2018 processes is the key to developing new ways to control the properties and state of the surface [2]. Thus, the study of structurally inhomogeneous systems based on high-temperature superconductors and systems with a developed surface and a phase transition (P. P. Gorbik, A.A.Chuiko, et al., 2003), modelling the interaction and reactivity of biomolecules with inorganic materials are of great interest [3].

Experimental and theoretical mineralogy, physical chemistry of synthesis of superhard carbon phases and other materials with specified physical characteristics are interested in studies on the nature of the significant difference in the surface energy of the faces of different crystallographic orientations of the same crystal. The reason for the demonstration of such a property, according to G. I. Distler, is the electrical structure of crystals. Through the example of modeling the structure of complexes formed as a result of the contact of the $\mathrm{H}_{2} \mathrm{O}$ molecule with atomically pure faces (111) and silicon (100), it was shown that the water molecule is adsorbed on the silicon surface exclusively dissociative with the high energy release [4]. Investigating the surface with allowance for the electrostatic potential in the surface layer of crystalline modifications of titanium dioxide V. V. Lobanov, V. I. Gorlov, et al. (1999) studied special aspects of molecular and dissociative water adsorption on various 
crystal faces. They have determined the effect of impurity metal ions on the adsorption properties of titanium oxide.

The chemical state of the surface, the type of physical action (heating, compression, stretching, shear, electric and magnetic field), the phase state and the component composition of the substance in contact with the surface, determine the direction of physical and chemical surface processes. One of the priority areas in the field of surface chemistry is such issues as the structure of nanodiamonds of detonation synthesis, the possibility of purposeful functionalization of clusters in order to attain required properties to the particles of nanodiamonds [5]. Detonation nanodiamonds are a very promising material in the field of nanobiotechnology. The physical and chemical properties of the surface of diamond nanoparticles are used to create systems for the delivery of drugs of a new generation. In these cases, a complex of physicochemical effects, the choice of a nanocarrier, its standardization and the method for immobilization of biologically active and medicinal substances are used to impart the required properties (production of hybrid nanomaterials) to the surface [6].

Assuming that the parameters and conditions of physical effects, the phase state, the component and chemical composition of the gas or liquid phase are constant, the chemical reactions pathway will be affected by electric charges and the density of their distribution on a solid surface. In one of their works M. I. Ozhovan and P. P. Poluektov (1987) determined the conditions for the spontaneous formation and growth of new phases on the surfaces of solid charged particles by the diffusion redistribution of material substance over the surface. They showed that for each particle size there is a certain threshold value of the density of charges on the surface, the excess of which leads to spontaneous growth of the new formations on the surface. The solution of problems in the field of controlling the processes of phase formation is especially important in the production of monocrystals, including the industrial synthesis of diamond.

In the 70-90s of the last century, a number of works by M. I. Molotsky showed that the catalytic activity of the exit sites of edge dislocations on the surface is related to the interaction of dislocations with the electrons of the surface layer of atoms and can be explained by:

1) formation of a strong two-electron bond of a chemisorbed atom with an electron localized at the dislocation core;

2) decrease in the thermodynamic barrier of the formation of a new phase nucleus in the field of a localized electron;

3 ) increase in the proportion of the reactive form of chemisorption near the dislocation core;

4) attraction of chemisorbed particles to the dislocation core;

5) formation of molecular ions on dislocations;

6) formation of a crystalline nucleus of a new phase at a temperature of $300 \mathrm{~K}$ near the edge dislocation, the probability of which increases by more than two dozen orders of magnitude;
7) the size of the crystalline embryo near the dislocation, which decreases by an order of magnitude in comparison with the ideal surface;

8) formation of a charged surface center, which leads to a marked increase in the rate of the heterogeneous process (especially at multiply charged centers);

9) the excitation of molecules moving at a transonic velocity by a dislocation is three orders of magnitude stronger than molecular collisions in a gas at the same velocities.

Taking into account even this limited list of the examples of catalytic activity of edge dislocations, a number of questions arise concerning the possibility of reactions between the Coulomb center and the chemical bond of the molecule (the problem of the bond stability in the charge field), the control of chemical reactions, the control of their rate and pathway, and so on. In general, the search and forecasting of answers is a task of the theory of chemical reactions. It should be noted that only the Coulomb interaction functions in the chemically reacting system. The parameter of this interaction is the dependence of energy on the distance between the reacting particles. Therefore, quantum-mechanical regularities are preferred in the modelling of the assumed scenario of events in a system of interacting particles [7].

Analysis of the recent research and publications. The idea of the dominant impact of electrical interactions in catalysis processes is set out in the basic concepts of the electron-chemical theory of catalysis, created in the first quarter of the $20^{\text {th }}$ century by L. V. Pisarzhevsky. This theory began to develop actively only in the second half of the last century, largely due to works of F. F. Volkenstein, S.Z. Roginsky N. N. Semenov, I. D. Sokolov, V. A. Roiter, N. P. Kaiser, O. V. Krylov, A. L. Buchachenko, K. Hauffe, L. Pauling, D. Dauden and many other prominent scientists.

Professor Gerhard Ertl, the Nobel Prize winner in Chemistry (2007), gave a detailed description for the development of chemical reactions on a solid surface [8]. Thus, he laid down the basis for modern surface chemistry. Ertl and colleagues showed that nitrogen is adsorbed on the surface of the catalyst in atomic form, described the kinetics of nitrogen adsorption, and explained the way of transformations. Investigating the process of $\mathrm{CO}$ molecule oxidation on platinum, regularities have been established that are used in catalysts for purifying automotive exhaust gases [9]. The quantitative evaluation of hydrogen adsorption on platinum is given for the first time; the limiting stage of the ammonia synthesis reaction on an iron catalyst is described in [10]. Studies on the choice and improvement of the catalysts' characteristics are developed actively [11].

Authors of a recent paper [12] have stated that they solved one of the long-standing mysteries of catalytic chemistry, connected with the choice of a chemisorption site by a molecule on the surface of a crystal. Thus, authors answered the question why the catalytic capacity of crystallographic surfaces of the same crystal can differ by a factor of hundreds. This interpretation of the way of molecules was explained selectivity by the change in the energy of molecule interaction with the surface, 
while it was noted that the potential energy of the surface has a very uneven landscape. However, in [12] and in the works of other researchers, unfortunately, the nature of a possible source of energy and the cause of its uneven distribution on surfaces is not discussed. One of the possible reasons for varying catalytic activity of different parts of the surface of the same crystal (for example, tungsten [12]) may be the presence of surface electric charges (V.V.Sobolev, et al., Mineralogical Journal, 1994). Charges on the particle cause a negative pressure on the surface (M. I. Ozhovan and P. P. Poluektov, 1987), as the potential energy of diffusing molecules changes in the near-surface electric field. They stated that since the field is modulated in accordance with the local curvature of the surface, the potential energy of the molecules is also modulated. On strongly curved sections of the surface, there are drift flows of substance, which may be bigger than diffusive ones. The curvature of the surface, the change in the potential energy of molecules, the competition between the drift and diffusion flows of substance, the electric field of the surface, shape fluctuations, and others are parameters interacting in the self-organization of substance and subject to the energy concept. The self-organization of substance in the gas-solid surface system "solves" a wide range of problems associated with controlling the rate and pathway of chemical reactions, "delivering" energy to reagents and where it is most favorable to "contribute" this energy. The theory of chemical reactions solves similar problems and, moreover, according to Academician of the Russian Academy of Sciences, A. L. Buchachenko, seeks ways and means of lifting the prohibition and controlling chemical reactions. One of these methods uses the laws of quantum-mechanical and Coulomb interactions.

Objectives of the article. One of the advantages of a surface gas-solid body over a gaseous medium consists in the possibility of isolating distinct contacts of gas reactants with surface active centers, and at the same time evaluates physicochemical laws of interaction and redistribution of energy between particles.

The development of the theory of catalysis is of great importance for the fundamental knowledge of modern chemistry, a number of important high-tech industries, up-to-date sectors in ecology, nanostructured materials science, biochemistry, photosynthesis, cosmochemistry and other applied research spheres.

Without pretending to the theory as a whole, we confine ourselves to studying only some, in our opinion, missing links in the theory of electron-chemical catalysis. Considering the mentioned above results of some scientific achievements, we will use the methods of quantummechanical modeling of the chemical bond stability of a molecule in the field of a point Coulomb center.

The purpose of the work is to establish the dependence of the change in the potential energy of the chemical bond of a diatomic molecule on the value of the point charge and its distance to the bond using quantum-mechanical calculations.

Presentation of the main research and explanation of scientific results. The quantum-mechanical model for determining the state of an electron in the field of two Coulomb centers is proposed as the basis for solving the problem of the interaction of molecular systems with surface structures of solids. It was suggested by G. O. Yarkovoy (Preprint of the Institute of Theoretical Physics of the Academy of Sciences of the USSR, ИТФ-7554R). The adiabatic Born-Oppenheim approximation is used in this paper (the motion of electrons is considered separately from the motion of nuclei, the distances between which are assumed to be fixed).

To solve the two-center problem, a model equation is derived from the Schrödinger equation, the solution of which is obtained in analytic form. Taking account of boundary conditions allowed us to find the quantum numbers that determine the state of the valence electron in the field of two Coulomb centers. Naturally, the obtained solution is approximate, since it represents the solution of the abridged Schrödinger equation and therefore can be considered as the zero approximation to the exact solution. The next logical step was to take into consideration the terms of the exact Schrödinger equation that were not used in the model equation as a perturbation to the zeroth-order approximation. The chosen approach is implemented with the Green's function, which is a solution of the model equation with delta-like sources. Knowledge of Green's function made it possible to determine the wave function of the basic state in the first approximation in an analytic form. The search for the following approximations in the analytical form is inexpedient for two reasons: the solutions are too lengthy and do not give a significant correction to the first approximation.

The quantum-mechanical problem has been tested in the calculations of diatomic molecules. Calculations showed that the model describes adequately the neutral and ionized hydrogen molecule. It is established that the application of this model to more complex molecules gives unsatisfactory results, due to the fact that the electron cores of bound atomic electrons screen the Coulomb potential. Therefore, solving the Poisson equation (averaged over directions in space), electric potentials created by bound electrons are found in the central field approximation. The nuclear charges entering into these equations were calculated according to Slater's rule. In addition, a new approach has been developed that includes the polarization of electronic cores during their mutual influence. At the same time solutions of the Poisson equation in the ellipsoidal coordinate system are obtained to find the potentials created by the valence electrons, which allows for additional screening of the nuclear potential by electrons providing a chemical bond in the molecule. Calculations showed that such a model allows us to calculate quantitatively quite complex diatomic molecules not only qualitatively, but also.

The solution of the problem of the interaction of molecular systems with surface structures is based on the solution of the problem of the influence of the external Coulomb potential on the molecular bond. This potential was considered as a perturbation to the model Schrödinger equation, and, therefore, it was possible to 
apply Green>s function to find the analytical solution. The solution was obtained in an ellipsoidal coordinate system in which the external potential was represented in the form of a Neumann expansion.

Charged surface structures of condensed matter, cluster molecular systems, and others are often described by linear atomic chains. In this context, the problem of quantization of an electron in the field of $\mathrm{N}$-Coulomb centers has been solved [13]. The obtained transformations made it possible to reduce the Schrödinger equations for the chain to the two-center problem. Along with this, an analytical solution of the problem of the influence of the third Coulomb Centre on the chain structure was obtained.

It is known that catalytic reactions on the surface of catalysts depend on the binding energy between the involved reagents. Considering the results of experimental studies on the component composition of reaction products and the way of catalytic transformations in various systems, it is of some interest to calculate the binding energy between atoms and how it affects the formation of new compounds. To evaluate the binding energy, the method of quantum mechanical calculations was used, which was tested earlier in [14].

The energy of a single chemical bond was calculated using the Schrödinger equation

$$
E=E_{1}+E_{e-e}+E_{\text {Coul }}+W_{1}+W_{2},
$$

where $E_{1}$ is the particle interaction energy for the solution of the two-center problem; $E_{e-e}$ is the electronelectron interaction energy; $E_{\text {Coul }}$ is the Coulomb energy; $W_{1}$ is the perturbation that occurs when solving the two-center problem; $W_{2}$ is the perturbation that creates the intercalated catalyst atom in the crystal lattice of the carbon phase.

The Schrodinger equation for an electron moving in the field of two Coulomb centers is represented in elliptic coordinates

$$
\begin{gathered}
\left\{\frac { 4 } { R ^ { 2 } ( \lambda ^ { 2 } - \mu ^ { 2 } ) } \left[\frac{\partial}{\partial \lambda}\left(\lambda^{2}-1\right) \frac{\partial}{\partial \lambda}+\frac{\partial}{\partial \lambda}\left(1-\mu^{2}\right) \frac{\partial}{\partial \lambda}+\right.\right. \\
\left.\left.+\frac{\lambda^{2}-\mu^{2}}{\left(\lambda^{2}-1\right)\left(1-\mu^{2}\right)} \frac{\partial^{2}}{\partial \varphi^{2}}\right]\right\} \psi+\frac{2 m}{\hbar^{2}}[E-U(\lambda, \mu)] \psi=0,
\end{gathered}
$$

where $\lambda=\frac{r_{1}+r_{2}}{R}, \mu=\frac{r_{1}-r_{2}}{R}, r_{1}, r_{2}$ are the distance from the electron to the first and up to the second atom, respectively; $R$ is the distance between atoms 1 and $2, \psi-$ is the wave function.

Equation (1) has a solution if the proposed potential $U(l, m, j)$ is given as the sum of the Coulomb potential $U_{\text {Coul }}$ and the fluctuating $U_{f}$ one [13]

$$
\begin{gathered}
U(\lambda, \mu, \varphi)=U_{\text {Coul }}(\lambda, \mu, \varphi)+U_{f}(\lambda, \mu, \varphi) ; \\
U_{\text {Coul }}(\lambda, \mu, \varphi)=\frac{2}{R}\left[\frac{Z_{1}}{\lambda+\mu}+\frac{Z_{2}}{\lambda-\mu}\right] ; \\
U_{f}(\lambda, \mu, \varphi)=\frac{R^{2} \omega^{2}}{8}\left(\lambda^{2}+\mu^{2}\right),
\end{gathered}
$$

where $\omega$ is the frequency of base oscillations of the atoms.

The binding energy was calculated using expression

$$
E_{k, \Lambda, n}=\frac{\left\langle\psi_{k, \Lambda, n}\left|H_{0}\right| \psi_{k, \Lambda, n}^{*}\right\rangle}{\left\langle\psi_{k, \Lambda, n} \mid \psi_{k, \Lambda, n}^{*}\right\rangle},
$$

where $H_{0}$ is Hamiltonian of the two-center problem; $\Psi_{k, \Lambda, n}$ is the wave function with quantum numbers $k$, $\Lambda, n$.

As a result of the solution of the Schrödinger equation (1) and the calculation of energy from formula (2), we obtain an expression for calculating the binding energy in the basic state

$$
E_{\frac{1}{2}, 0,0}=\frac{4\left[\frac{1}{2}\left(a-Z^{+}\right)+e^{4 a} \cdot E_{i}(-4 a) \cdot\left(a^{2}-a \cdot Z^{+}-\frac{1}{4} a\right)\right]}{R^{2}\left[\frac{1}{2 a}-\frac{4}{3} a \cdot e^{4 a} \cdot E_{i}(-4 a)\right]},
$$

where $Z^{+}=Z_{1}+Z_{2}, Z_{1}, Z_{2}$ are charges of interacting atoms, $a=0.5+\sqrt{\left(Z_{1}+Z_{2}\right) R}$.

The calculation of electron-electron interactions was carried out using the Slater determinant

$$
\begin{aligned}
E_{e-e} & =\left\langle\psi_{\mathrm{det}}\left|\frac{1}{r_{1,2}}\right| \psi_{\mathrm{det}}^{*}\right\rangle=\frac{4}{R\left[\frac{1}{2 a}-\frac{4}{3} a \cdot e^{4 a} \cdot E_{i}(-4 a)\right]^{2}} \times \\
\times & {\left[\left(\frac{3}{40 a^{2}}+\frac{1}{20 a^{2}}\right) \cdot(C+\ln 2 a)+e^{8 a} E_{i}^{2}(-8 a) \times\right.} \\
& \times\left(\frac{3}{40 a^{2}}+\frac{11}{20 a}+\frac{7}{5}+\frac{8 a}{15}\right)+e^{4 a} E_{i}^{2}(-8 a) \frac{4 a^{2}}{15}+ \\
& \left.+e^{4 a} E_{i}^{2}(-4 a)\left(-\frac{3}{20 a^{2}}+\frac{1}{2 a}-\frac{1}{5}\right)+\frac{1}{8 a}-\frac{1}{10}\right] .
\end{aligned}
$$

In order to account for the effect of the interstitial active catalyst atom, let us consider the effect of the Coulomb center (electric charge) on the stability of the chemical bond. Put the case that some perturbation acts on the bond

$$
\begin{aligned}
& W_{2}=\frac{2 Z_{3}}{R} \sum_{p=0}^{\infty} \sum_{m=-p}^{p}(-1)^{m}(2 p+1)\left[\frac{(p-|m|) !}{(p+|m|) !}\right] \times \\
& \times P_{p}^{|m|}\left(\lambda_{<}\right) Q_{p}^{|m|}\left(\lambda_{>}\right) P_{p}^{|m|}\left(\mu_{3}\right) Q_{p}^{|m|}\left(\mu_{3}\right) e^{i m\left(\varphi-\varphi_{3}\right)}
\end{aligned}
$$

where $Z_{3}$ is a charge of a catalyst atom, $\lambda_{3}=\frac{R_{1}+R_{2}}{R}$; $\mu_{3}=\frac{R_{1}-R_{2}}{R} ; R_{1}$ is the distance from the atom-catalyst to the first atom; $R_{2}$ is the distance from the atom-catalyst to the second atom - the bigger or smaller of the values; $P_{p}^{|m|}\left(\lambda_{<}\right)$and $Q_{p}^{|m|}\left(\lambda_{>}\right)$are associated Legendre functions of the first and second kinds.

Then, taking into account the perturbation, the energy of the chemical bond will be 


$$
\begin{gathered}
E_{0}\left(R_{1}, R_{2}, R_{3}\right)=\frac{\left\langle\psi\left|H+W_{1}+W_{2}\right| \psi^{*}\right\rangle}{\left\langle\psi \mid \psi^{*}\right\rangle}+E_{0}\left(R_{1}\right)+ \\
+\sum_{i=1}^{N} \frac{4 a Z_{i}}{R_{i}\left[\frac{1}{2 a}-\frac{4 a}{3} e^{4 a} E_{i}(-4 a)\right]}\left\{Q _ { 0 } ^ { 0 } ( \lambda _ { 2 } ) \left[\frac{2}{3} e^{4 a} E(-4 a)-\right.\right. \\
\left.-\frac{1}{4 a^{2}}\right]-\frac{1}{8 a^{2} e^{2 a\left(\lambda_{2}-1\right)}}\left[P_{2}\left(\lambda_{2}\right) P_{2}\left(\mu_{2}\right)-1\right] .
\end{gathered}
$$

The developed method for calculating the electronic molecular terms with regard to the screening of nuclear potentials by the electron cores of bound electrons has been tested through the example of calculations of the electronic terms of $\mathrm{CO}, \mathrm{O}_{2}, \mathrm{~N}_{2}, \mathrm{LiH}, \mathrm{H}_{2}, \mathrm{Li}_{2}$ and $\mathrm{HCl}$ molecules (Fig. 1).

Molecules of $\mathrm{H}_{2}, \mathrm{LiH}, \mathrm{HCl}$, and $\mathrm{Li}_{2}$ have two valence electrons in the $(1 / 2 ; 0 ; 0)$ state. The electron cores of atoms are absent in the hydrogen molecule, therefore the polarization coefficient $k_{n \mathrm{H}}=1$. The terms of the molecules $\mathrm{LiH}$ and $\mathrm{HCl}$ illustrate the electron core of lithium and chlorine, which deforms toward the "uncoated" hydrogen nucleus (Fig. 1). The lithium polarization coefficient $k_{n \mathrm{Li}}=2.07$, chlorine $-k_{n \mathrm{Cl}}=1.025$.

The lithium molecule is the most difficult to calculate, since its interaction energy of electron cores is comparable with the energy of interaction of nuclear charges. This explains the high polarization coefficient $k_{n \mathrm{Li}}=1.8283$.

Â nitrogen molecule is complex; six electrons form a valence bond, the first pair of which is in the state $(1 / 2$; $0 ; 0)$, the second pair $-(3 / 2 ; 0 ; 0)$; the third pair $-(5 / 2$; $0 ; 0)$; the polarization coefficient $-k_{n}=1.21638$.

The valent bonds of the $\mathrm{O}_{2}$ and $\mathrm{CO}$ molecules are formed by two pairs of electrons in the $(1 / 2 ; 0 ; 0)$ and $(3 / 2 ; 0 ; 0)$ states. The polarization coefficients are $k_{n \mathrm{O}_{2}}=1.37$ and $k_{n \mathrm{O}}=1.31952$.

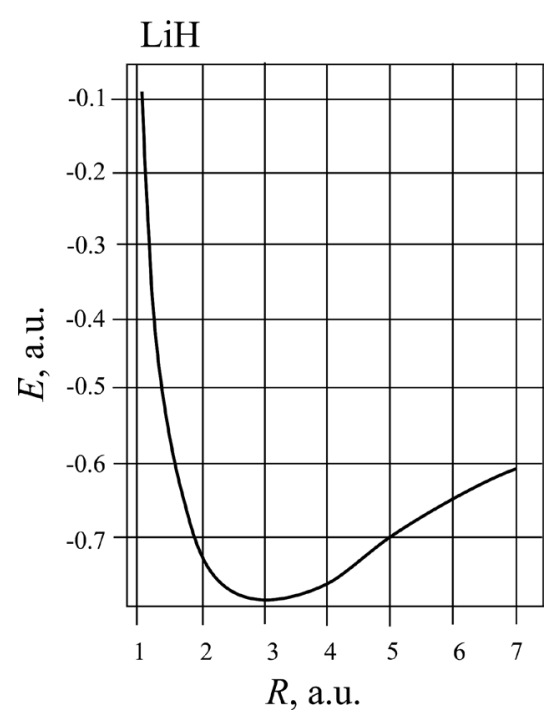

$a$

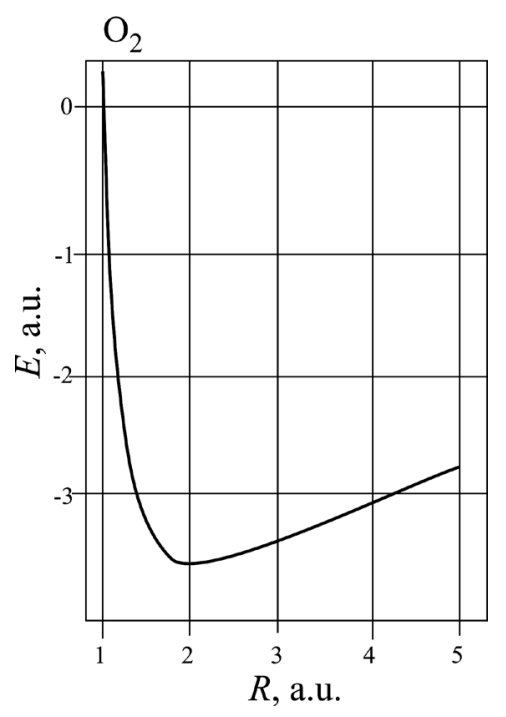

$d$

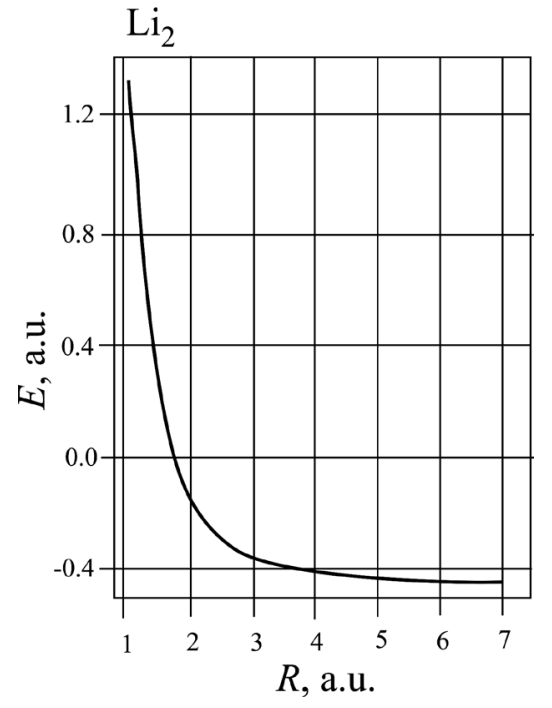

$b$

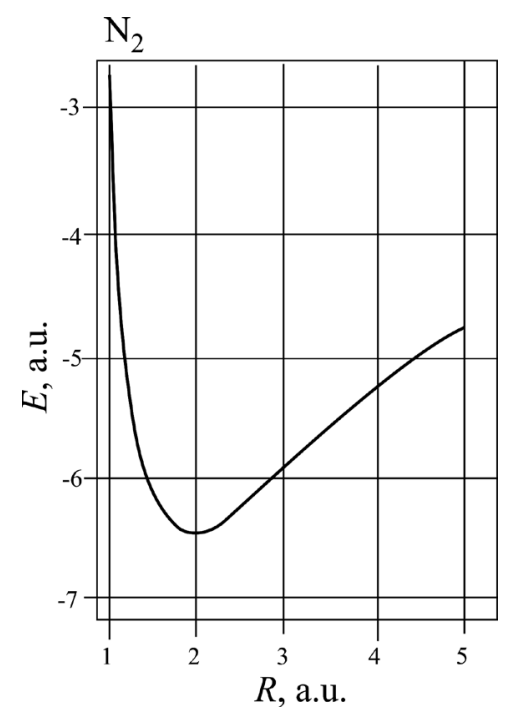

e

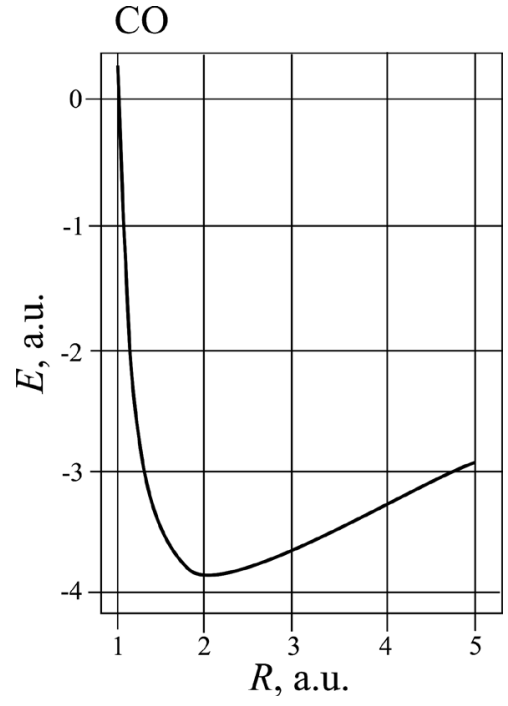

$c$

$\mathrm{HC} 1$

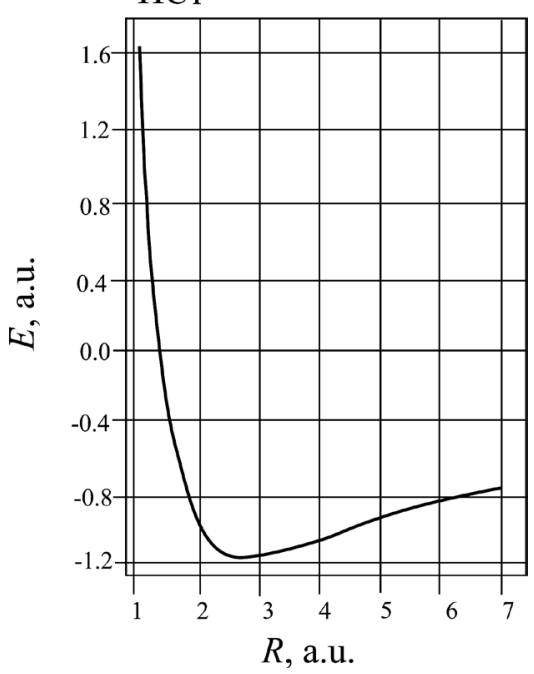

$f$

Fig. 1. Electronic terms of diatomic molecules:

$a-\mathrm{LiH} ; b-\mathrm{Li}_{2} ; \mathrm{c}-\mathrm{CO} ; \mathrm{d}-\mathrm{O}_{2} ; e-\mathrm{N}_{2} ; \mathrm{f}-\mathrm{HCl}$ 
The calculated values of the equilibrium internuclear distances $\left(R_{0}\right)$, the energy minima $(E)$ corresponding to them and the experimental data given in the papers of A.A. Radzig, E. M.Smirnov and other researchers are presented in Table.

It is seen from the table that the characteristics of the molecules obtained by the authors using the proposed technique have satisfactory accuracy and are quite coherent with the experimental data. It gives evidence of the correctness of the estimates of molecules parameters using the developed technique. This technique was used in solving problems to determine the stability of chemical bonds of molecules.

Fig. 2 shows the dependence of the chemical bonding energy of the nitrogen molecule on the effect of point electric charges, which is located at a distance of $2.5 \cdot 10^{-10} \mathrm{~m}$ from the bond of the molecule. The electric field strength of a singly charged ion at a distance of $10^{-9} \mathrm{~m}$ is $\sim 1.5 \cdot 10^{9} \mathrm{~V} / \mathrm{m}$. As the distance to the ion decreases, the intensity increases. At a temperature of $0 \mathrm{~K}$, at some (critical) distance, the chemical bond of any molecule breaks down. In general, the effect of the charge field (the Coulomb center) on the molecule leads to a "loosening" of the chemical bond. Obviously, as the distance from the molecule increases, the effect of the charge declines.

Fig. 3 shows the dependence of the change in the minimum binding energy of a diatomic nitrogen molecule under the influence of an external charge $Z=+10$. Estimation of the distance at which the chemical bond breaks was $H=2.73$ a.u. Fig. 2 depicts a curve 3 which does not have a minimum of energy. It testifies to bond breaking at a distance of 4.7 a.u. from the charge $\mathrm{Z}=+8$.

The scenario of the change in the binding energy of the $\mathrm{N}_{2}$ molecule (Fig. 2) is similar for other small molecules $\mathrm{O}_{2}, \mathrm{CO}_{2}, \mathrm{CO}$, and so on. According to the results of calculations, the trend is held, and the change in binding energy to a great extent depends on both the sign, the magnitude of the charge, and the molecular distance from the charge. The thermodynamic equilibrium of the system is continued to apply when these reactions proceed.

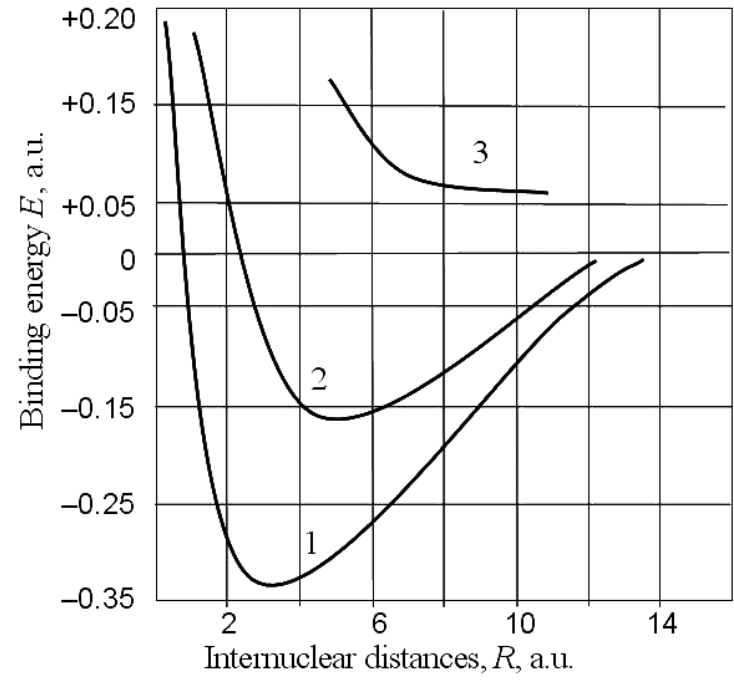

Fig. 2. Change in the potential binding energy $E(R)$ of the $N_{2}$ molecule in the field of the negative charge:

$1-Z=+2) ; 2-Z=+4) ; 3-Z=+8$ at a distance of 4.7 a.u. from the charge

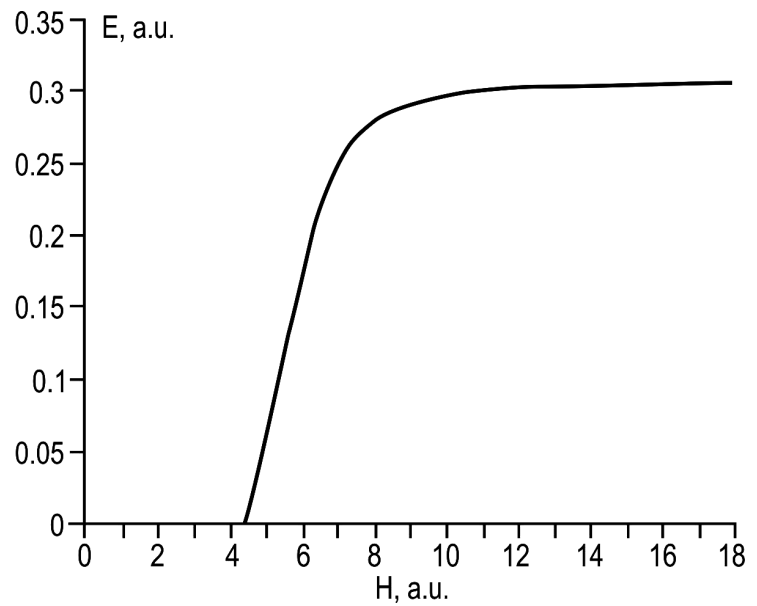

Fig. 3. Dependence of the minimum value of the energy of the interatomic bond $(E)$ on the distance $(H)$ of the diatomic nitrogen molecule to the third center with charge $Z=+10$

Table

Comparative characteristics of diatomic molecules

\begin{tabular}{|l|c|c|c|c|c|}
\hline \multirow{2}{*}{ Molecule } & \multirow{2}{*}{$\begin{array}{c}\text { Dissociation } \\
\text { energy } D, \mathrm{eV}\end{array}$} & \multicolumn{2}{|c|}{$\begin{array}{c}\text { Experimental data } \\
\text { (reference data) }\end{array}$} & $\begin{array}{c}\text { Theoretical values } \\
\text { (obtained in this paper) }\end{array}$ \\
\cline { 3 - 6 } & & $\begin{array}{c}\text { distance between } \\
\text { atoms } R, \text { a. u. }\end{array}$ & $\begin{array}{c}\text { binding energy } \\
E, \text { a. u. }\end{array}$ & $\begin{array}{c}\text { distance between } \\
\text { atoms } R, \text { a. u. }\end{array}$ & $\begin{array}{c}\text { binding energy } \\
E, \text { a. u. }\end{array}$ \\
\hline $\mathrm{LiH}$ & 2.46 & 3.0576 & -0.0906 & 3.0150 & -0.088 \\
\hline $\mathrm{Li}_{2}$ & 1.26 & 5.0626 & -0.0410 & 5.0500 & -0.043 \\
\hline $\mathrm{CO}$ & 11.15 & 2.1697 & -0.4010 & 2.1323 & -0.351 \\
\hline $\mathrm{O}_{2}$ & 6.65 & 2.322 & -0.1896 & 2.3123 & -0.185 \\
\hline $\mathrm{N}_{2}$ & 8.73 & 2.104 & -0.3614 & 2.0680 & -0.366 \\
\hline $\mathrm{HCl}$ & 4.47 & 2.5394 & -0.1645 & 2.4470 & -0.153 \\
\hline $\mathrm{H}_{2}$ & 4.51 & 1.426 & -0.1660 & 1.4021 & -1.161 \\
\hline
\end{tabular}


If the molecule is near the charge, but not at a critical distance, the bond is "loosened" as the temperature rises, the interatomic distance increases, the binding energy decreases and the bond breaks. In general, the dynamics of the decrease in the binding energy of the molecule qualitatively repeats the result of the charge action with the approach of the molecule. An increase in the critical distance from the charge, upon reaching which the chemical bond of the molecule is broken, occurs with an increase in charge.

Thus, during numerical experiments, a tendency has been established to reduce the energy of interatomic interactions in the presence of ions as a function of the magnitude of the ion charge and the distance between the molecule and the ion. The distance from the ion at which the bond breaks up, increases with increasing ion charge and charge distribution density on the surface or with increasing temperature, all other conditions being equal. For $\mathrm{H}_{2}$ molecules, the bond breakdown occurs at larger distances from the charge than in $\mathrm{N}_{2}$.

The features of the change in the stability state of the $\mathrm{CO}$ chemical bond in the field of the Coulomb center located on the surface of the solid carbon phase are illustrated in Fig. 4. A diatomic CO molecule with a stable chemical bond entering the zone of influence of the electric charge - the metal ion is shown in Fig. 4, $a$. Fig. $4, b$ shows that the chemical bond is "loosening" in the field of the ion charges. The bond at a certain (critical) distance breaks, Fig. 4, c, and Fig. 4, $d$ shows the formation stage of the metal oxide and the incorporation of the carbon atom into the surface layer of the crystal lattice of the carbon phase. The $\mathrm{C}-\mathrm{C}$ bond develops into more advantageous than the hybrid $\mathrm{Me}-\mathrm{C}$ bond ( $\mathrm{Me}$ - the metal atom). The $\mathrm{Me}-\mathrm{O}$ compound can leave the surface of the solid phase or "fixate" on it. In the latter case, the proposed mechanism for the origin of a new phase on the surface is the mechanism for the formation of syngenetic inclusions in minerals.

A number of new physical effects have been established as a result of studies on phase and structural transformations of some carbonate minerals, rocks, coals and anthracites under heating and simultaneous action of a weak electric field [13, 14]. It should be noted that these effects do not exert under the influence of just one of any factors.

Conclusions. In a physicochemical system that is in a state of thermodynamic equilibrium the initiation and development of a chemical reaction can be stimulated by the action of a point electric charge on a chemical bond, without changing the thermodynamically equilibrium state of the system.

The preference of a particular crystallographic plane by the molecule is due to such parameters as the value of the point electric charges and the density of their distri-

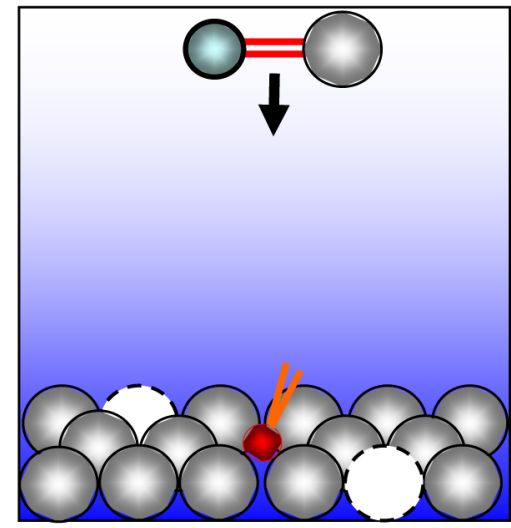

$a$

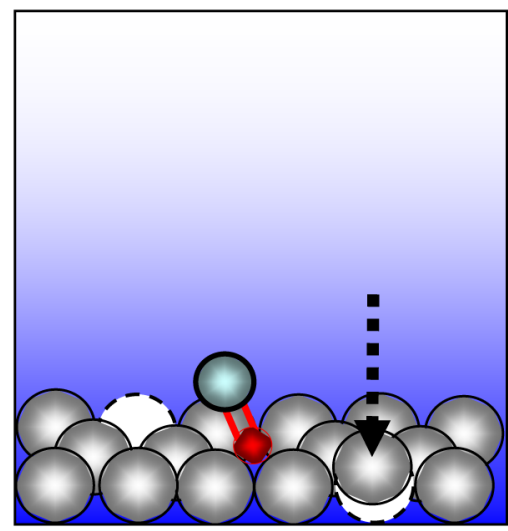

$d$

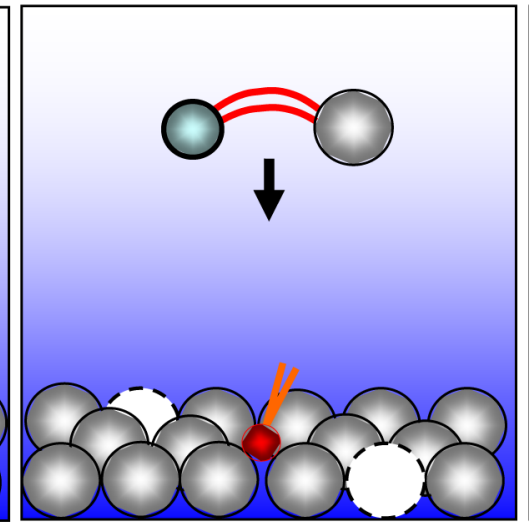

$b$

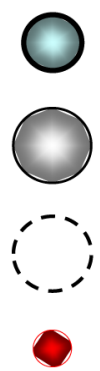

oxygen atom

carbon atom

vacancy

metal ion (catalyst)

Fig. 4. A possible scenario for the dynamics of an elementary chemical event occurring on the surface of a solid phase in front of a point Coulomb center (a metal ion) 
bution in accordance with the curvature of the surface, which (with other equal conditions) is sufficient to break the chemical bonds of the molecule with maximum probability.

The long-distance effect of a solid surface on the state of the bond stability of every single molecule, the initiation of surface chemical reactions, adsorption processes, and the formation of nuclei of new phases may be due not only to Coulomb interactions, but also to certain regularities of quantum action at a distance.

The represented elementary act of involution of the state of chemical bond stability of a diatomic molecule in the field of influence of a point charge is the result of solving the problem of three Coulomb centers. It is shown that the decrease in the energy of the interatomic bond occurs as the molecule approaches the charge. The breaking of the bond of any molecule always occurs (for all other equal conditions) at the same distance from the charge. The critical distances for molecules with the highest energy of interatomic bonds are the smallest.

Critical distances for molecules with the lowest binding energy are characterized by maximum values. Under the condition of additional temperature effect, for example, up to $300 \mathrm{~K}$, when the molecule approaches the point charge the bond breaking occurs at distances several times exceeding the critical temperature, which are characteristic for temperature $0 \mathrm{~K}$. The temperature, pressure and electric field strength stimulates the onset of phase transformations under the lower values than under the action only pressure and temperature. In practical work, catalytic reactions are used in many physicochemical processes, for instance, in the high-energy physical processes of the formation of new elements [15], the formation of plasma at super deep penetration of microparticles into metals [16], in the underground coal gasification [17], in waste water treatment [18], etc.

In general, the results of the studies are no different fundamentally from Professor Ertl's results, despite the fact that various theoretical approaches and experimental methods were used to solve the problems. However, in our opinion, the quantum-mechanical approach is still more promising, since it considers the presence of surface charges - energy sources, the surface effect on the reaction behavior, reveals the physics of the mechanism of charge interaction with chemical bonds and their most important role in catalytic reactions.

\section{References.}

1. Kartel, N. T. and Lobanov, V. V., eds., 2015. Physics of Surface (in 2 volumes). In: Physics and Chemistry of Surface. Kyiv: Interservis. Book 1.

2. Sychov, M. M., Minakova, T.S., Slizhov, Ju. G. and Shilova, O.A., 2016. Acid-basic characteristics of the surface of solids and properties control of materials and composites. St. Petersburg: Himizdat.

3. Rimola, A., Costa, D., Sodupe, M., Lambert, J.F. and Ugliengo, P., 2013. Silica Surface Features and Their Role in the Adsorption of Biomolecules: Computational Modeling and Experiments. Chem. Rev., 113(6), pp. 4216-4313. DOI: 10.1021/cr3003054.
4. Terebinska, M. I. and Lobanov, V. V., 2008. Dissociate Adsorption of Water Molecule on Unrelaxed (111) and (100) Faces of Crystalline Silicon. Physics and chemistry of solid state [pdf], 9(1), pp. 135-137. Available at: <http://www.pu.if.ua/inst/phys_che/start/ pcss/vol9/0901-21.pdf $>$ [Accessed 11 April 2017].

5. Shugalei, I. V., Sudarikov, A. M., Voznyakovskii, A. P., Tselinskii, I.V., Garabadzhiu, A. V. and Ilyushin M.A., 2012. Chemistry of the surface of detonation nanodiamonds as a basis for creating biomedical products. St. Petersburg: Pushkin Leningrad State University [online]. Available at: <https://search.rsl.ru/ru/record/01006552987> [Accessed 25 May 2017].

6. Yakovlev, R. Y., Kulakova, I. I., Badun, G. A., Lisichkin, G. V., Valueva, A. V., Seleznev, N. G. and Leonidov, N.B., 2016. Physical-chemical principles of the preparation of hybrid materials on the basis of detonation nanodiamonds as a new generation drug delivery systems and their properties. Drug Developments \& Registration, 3(16), pp. 60-66.

7. Huzihiro Araki, Berthold-Georg Englert, Leong-Chuan Kwek and Jun Suzuki, eds., 2010. Mathematical Horizons for Quantum Physics. Lecture Notes Series, Institute for Mathematical Sciences, National University of Singapore: Volume 20.

8. Ertl, G., 2007. Chemical Processes on Solid Surfaces. Scientific Background on the Nobel Prize in Chemistry. Stockholm, Sweden [pdf]. Available at: <https://www. nobelprize.org/nobel_prizes/chemistry/laureates/2007/ advanced-chemistryprize2007.pdf> [Accessed 24 February 2017].

9. Kim, M., Bertram, M., Pollmann, M., von Oertzen, A., Mikhailov, A.S., Rotermund, H.H. and Ertl, G., 2001. Controlling chemical turbulence by global delayed feedback: Pattern formation in catalytic CO oxidation on Pt(110). Science, 292, pp. 1357-1360. DOI: 10.1126/science.1059478.

10. Ertl, G., 2017. Molecules at Solid Surfaces: A Personal Reminiscence. Annual Review of Physical Chemistry, 68, pp. 1-17. DOI: 10.1146/annurev-physchem052516-044758.

11. Gebert, S., Cai, Y. and Kniep, B., 2012. Highly efficient catalysts for ammonia synthesis AmoMax by Süd-Chemie company. Kataliz v promyshlennosti, 4, pp. 13-17. DOI:10.18412/1816-0387-2012-4-13-17.

12. Alducin, M., D1'ez Muino, R., Busnengo, H. F. and Salin, A., 2006. Why $\mathrm{N}_{2}$ Molecules with Thermal Energy Abundantly Dissociate on $\mathrm{W}(100)$ and Not on W(110). Physical review letters, 97, 056102 (4). DOI: 10.1103/PhysRevLett.97.056102.

13. Sobolev, V. V., Bilan, N. V. and Khalymendyk, A. V., 2017. On formation of electrically conductive phases under electrothermal activation of ferruginous carbonates. Naukovyi Visnyk Natsionalnoho Hirnychoho Universytetu, 4, pp. 27-35.

14. Soboliev, V., Bilan, N. and Samovik, D., 2013. Magnetic stimulation of transformations in coal. In: Annual Scientific-Technical Collection - Mining of Mineral Deposits. CRC Press/Balkema, pp. 221-225.

15. Sobolev, V. V., Baskevich, A.S., Shiman, L. N. and Usherenko, S.M., 2016. Mechanism of thick metal 
walls penetration by high-speed microparticles. Naukovyi Visnyk Natsionalnoho Hirnychoho Universytetu, 6, pp. 74-82.

16. Sobolev, V. V. and Usherenko, S. M., 2006. Shockwave initiation of nuclear transmutation of chemical elements. J. Phys. IV France. 134, August 2006. EURODYMAT $2006-8^{\text {th }}$ International Conference on Mechanical and Physical Behaviour of Materials under Dynamic Loading. pp. 977-982. DOI: 10.1051/jp4: 2006134149.

17. Dychkovskyi, R. O., 2015. Determination of the rock subsidence spacing in the well underground coal gasification. Naukovyi Visnyk Natsionalnoho Hirnychoho Universytetu. 6, pp. 30-36.

18. Caceres, E. and Alca, J. J., 2016. Potential For Energy Recovery From A Wastewater Treatment Plant. IEEE Latin America Transactions, 14(7), pp. 3316-3321. DOI:10.1109/tla.2016.7587636.

\section{Електричні заряди як каталізатори хімічних реакцій на твердій поверхні \\ В. В. Соболєв ${ }^{1}$, Н. В. Білан ${ }^{1}$, О. С. Баскевич ${ }^{2}$, Л. І. Стефанович ${ }^{3}$}

1 - Державний вищий навчальний заклад „Національний гірничий університет“, м. Дніпро, Україна, e-mail: velo1947@ukr.net

2 - Державний вищий навчальний заклад „Український державний хіміко-технологічний університет“, м. Дніпро, Україна, e-mail: abaskevich@ukr.net

3 - Інститут фізики гірничих процесів Національної академії наук України, м. Дніпро, Україна, e-mail: listef2591@ ukr.net

Мета. Встановити залежність зміни потенційної енергії хімічного зв'язку двоатомних молекули від величини точкового заряду та його відстані до зв' язку з використанням квантово-механічних розрахунків.

Методика. Чисельне моделювання квантовомеханічної системи, що складається зі взаємодіючих між собою точкового заряду й молекули, яка складається із двох атомів.

Результати. Вирішено квантово-механічну задачу про вплив зовнішнього кулонівського центру на хімічний зв’язок двоатомних молекул.

Наукова новизна. Розроблена квантово-механічна модель фізичної системи, що складається зі взаємодіючих трьох кулонівських центрів, між двома 3 яких діє хімічний зв'язок. Модель дозволяє зрозуміти динаміку взаємодії молекули з іоном, заряд якого може характеризуватися як цілими, так і дробовими числами. Встановлена тенденція зміни енергії хімічного зв'язку в полі іона в залежності від відстані до зв'язку й величини заряду.

Практична значимість. Розроблена методика розрахунку енергії хімічного зв'язку в залежності від величини електричного заряду використана при розробці способу вирощування монокристалів метастабільного алмазу, у розрахунках меж стійкості хімічного зв'язку в азидах металів, у розробці механізму утворення додаткових шкідливих газів під час руйнування гірських порід вибухом і при розрахун- ку стійкості нанорозмірних вуглеводневих ланцюжків у кам'яному вугіллі та ін. Метод може бути використаний під час вибору каталізатора та управлінні каталітичними реакціями.

Ключові слова: каталіз, електрон, заряд, моделювання, квантова механіка, хімічний зв'язок

\section{Электрические заряды как катализаторы химических реакций на твердой поверхности}

\author{
В. В. Соболев ${ }^{1}$, Н. В. Билан ${ }^{1}$, А. С. Баскевич ${ }^{2}$, \\ Л. И. Стефанович ${ }^{3}$
}

1 - Государственное высшее учебное заведение „Национальный горный университет“, г. Днепр, Украина, e-mail: velo1947@ukr.net

2 - Государственное высшее учебное заведение „Украинский Государственный химико-технологический университет“, г. Днепр, Украина, e-mail: abaskevich@ukr.net 3 - Институт физики горных процессов Национальной академии наук Украины, г. Днепр, Украина, e-mail: listef2591@ukr.net

Цель. Установить зависимость изменения потенциальной энергии химической связи двухатомной молекулы от величины точечного заряда и его расстояния до связи с использованием квантовомеханических расчетов.

Методика. Численное моделирование квантово-механической системы, состоящей из взаимодействующих между собой точечного заряда и молекулы, состоящей из двух атомов.

Результаты. Решена квантово-механическая задача о влиянии внешнего кулоновского центра на химическую связь двухатомных молекул.

Научная новизна. Разработана квантово-механическая модель физической системы, состоящей из взаимодействующих трех кулоновских центров, между двумя из которых действует химическая связь. Модель позволяет понять динамику взаимодействия молекулы с ионом, заряд которого может характеризоваться как целыми, так и дробными числами. Установлена тенденция изменения энергии химической связи в поле иона в зависимости от расстояния до связи и величины заряда.

Практическая значимость. Разработанная методика расчета энергии химической связи в зависимости от величины электрического заряда использована при разработке способа выращивания монокристаллов метастабильного алмаза, в расчетах пределов устойчивости химической связи в азидах металлов, в разработке механизма образования дополнительных вредных газов при разрушении горных пород взрывом и при расчете устойчивости наноразмерных углеводородных цепочек в каменных углях и др. Метод может быть использован при выборе катализатора и управлении каталитическими реакциями.

Ключевые слова: катализ, электрон, заряд, моделирование, квантовая механика, химическая связь

Рекомендовано до публікації докт. техн. наук Д. В. Рудаковим. Дата надходження рукопису 21.04.17. 